Фесенюк Наталія Петрівна, магістр психології, докторант кафедри психології ПрАТ «ВНЗ «МАУП»; 02000, вул. Фрометівська, 2, м. Київ, Україна; >nataly_kadin_fesenyuk@ukr.net>; +38 (097) 422-12-99

ORCID: https://orcid.org/0000-0002-0461-641

Коляденко Ніна Володимирівна, доктор медичних наук, доцент, завідувач кафедри медичної психології ПрАТ «ВНЗ «МАУП»; 02000, вул. Фрометівська, 2, м. Київ, Україна; nina-k@ukr.net; +38 (067) 756-72-57

ORCID: https://orcid.org/0000-0003-2099-0163

Романенко Свген Олександрович, доктор наук із державного управління, магістр психології, професор, Заслужений юрист України, проректор ПрАТ «ВНЗ «МАУП»; 02000, вул. Фрометівська, 2, м. Київ, Україна; poboss1978@gmail.com

ORCID: https://orcid.org/0000-0003-2285-0543 Здоровенко Наталія Вікторівна, психолог Спеціальної загальноосвітньої школи «Надія»; 03057, вул. Академіка Янгеля, 12/2, м. Київ, Україна; zdor_nat@ukr.net; +38 (097) 255-0-444

ORCID: https://orcid.org/0000-0002-6636-7628

\title{
ВПЛИВ СПІЛКУВАННЯ З ТВАРИНАМИ НА ПСИХІЧНІ СТАНИ ДІТЕЙ $З$ ПСИХОНЕВРОЛОГІЧНИМИ ЗАХВОРЮВАННЯМИ ТА
} ВАДАМИ ЗОРУ

\begin{abstract}
Анотація
Ключові слова: зоотерапія, психокорекція, діти 3 психоневрологічними захворюваннями, діти 3 вадами зору, діти 3 інвалідністю
\end{abstract}

Постановка проблеми. В джерелах наукової літератури відсутня чітка класифікація та структура негативних психічних станів щодо переважання чи 
наявності їх окремих видів в тому чи іншому віковому періоді, є недостатнім відповідний психодіагностичний інструментарій, залишаються недостатньо розробленими i теоретично обгрунтованими методики психокорекції негативних психічних станів. Серед рекомендацій психокорекційних втручань немає методики анімалотерапії, дане питання взагалі недостатньо розроблене та мало висвітлене в наукових джерелах, в той час як у всьому світі використання тварин-асистентів з лікувально-реабілітаційною метою стає все більш популярним і поширеним, що спостерігається також і в Україні.

Формулювання мети статті: обгрунтувати зоопсихологічні механізми та визначити ефективність психокорекційного впливу тварин.

Виклад основного матеріалу. В результаті спостереження за реакціями дітей на тварин і ставленням до них, нами було виокремлено чотири типи реагування: I - адекватні реакції ( $~ 65 \%)$; II - не зовсім адекватні реакції ( $\approx 23 \%)$; III - зовсім неадекватні реакції ( $\approx 7 \%$ ); IVнесприйняття тварини (відсутність реакції) ( $\approx 5 \%)$.

Спілкування з тваринами знижує прояви агресії, позитивно впливає на комунікативність та емоційний стан особистості. Накопичення агресивності, в поєднанні зі зниженням комунікативних зв’язків, обмеженням спілкування, нестачею позитивних емоцій, може спричинити виникнення негативних психічних станів та призвести до невротизації особистості. Спілкування ж із тваринами в процесі психокорекції, дозволяє знизити поріг агресивності, що має важливе психопрофілактичне значення.

Висновки. Психологічна корекція на основі зоотерапії, завдяки тому, що взаємодія організовується опосередковано, через тварин, допомагає вирішити комунікативно-особистісні проблеми, створити позитивну мотивацію успіху, знизити прояви негативних форм поведінки та невмотивованої агресії, розширити спектр виявлення емоцій, надає можливість зняти психоемоційне напруження, оптимізувати очікування та спрямувати активність. 


\section{Аннотация}

Фесенюк Н. П., магистр психологии, докторант кафедры психологии ПрАТ «ВНЗ «МАУП»; Коляденко Н. В., доктор медицинских наук, доцент, заведующая кафедрой медицинской психологии ПрАТ «ВНЗ «МАУП»; Романенко Е. А., доктор наук по государственному управлению, магистр психологии, профессор, Заслуженный юрист Украины, проректор ЧАО «ВУЗ «МАУП»; Здоровенко Н. В., психолог Специальной общеобразовательной школы «Надежда»; г. Киев, Украина. Влияние общения с животными на психические состояния детей с психоневрологическими заболеваниями и нарушениями зрениями.

Ключевые слова: зоотерапия, психокоррекция, дети с психоневрологическими заболеваниями, дети с нарушениями зрения, дети с инвалидностью.

Постановка проблемы. В источниках научной литературы отсутствует четкая классификация и структура негативных психических состояний в отношении преобладания или наличия их отдельных видов в том или ином возрастном периоде, является недостаточным соответствующий психодиагностический инструментарий, остаються недостаточно разработанными и теоретически обоснованными методики психокоррекции негативних психических состояний. Среди рекомендацій психокоррекционных вмешательств отсутствует методика анималотерапии, этот вопрос вообще недостаточно разработан и мало освещен в научных источниках, в то время когда во всем мире использование животныхассистентов с лечебно-реабилитационной целью становится все более популярным и распространенным, что наблюдается также в Украине.

Формулирование цели статьи: обосновать зоопсихологические механизмы и оценить эффективность психокоррекционного воздействия животных.

Изложение основного материала. В результате наблюдения за реакциями детей на животных и отношением к ним, нами были выделены 
четыре типа реагирования: I - адекватные реакции ( $~ 65 \%)$; II - не вполне адекватные реакции ( $\approx 23 \%)$; III - абсолютно неадекватные реакции $(\approx 7 \%)$; IV- непринятие животного (отсутствие реакции) $(\approx 5 \%)$.

Общение с животными снижает проявления агрессии, позитивно влияет на коммуникативность и эмоциональное состояние личности. Накопление агрессивности, в соединении с уменьшением коммуникативных связей, ограничением общения, недостатком позитивних эмоций, может вызвать появление негативних психических состояний и привести к невротизации личности. Общение с животными в процессе психокоррекции позволяет снизить порог агрессивности, что имеет важное психопрофилактические значение.

Выводы. Психологическая коррекция на основе зоотерапии, благодаря тому, что взаимодействие организовывается опосредованно, через животных, помогает решить коммуникативно-личностные проблемы, создать позитивную мотивацию успеха, снизить проявление негативних форм поведения и немотивированной агрессии, расширить спектр проявления эмоций, предоставляет возможность снять психоэмоциональное напряжение, оптимизировать ожидания и направить активность.

\section{Annotation}

Fesenyuk NP, Magister of Psychology, PhD student of the Department of Psychology of the Private Joint-Stock Company "Higher Educational Institution "Interregional Academy of Personnel Management"; Kolyadenko NV, PhD, MD, Associate Professor, Head of the Department of Medical Psychology of the Private Joint-Stock Company "Higher Educational Institution "Interregional Academy of Personnel Management"; Romanenko YeA, PhD, Doctor of Science in Public Administration, Magister of Psychology, Professor, Honored Lawyer of Ukraine, Vice-Rector of Private Joint-Stock Company "Institute of Higher Education" MAUP "; Zdorovenko NV, Psychologist of the Special General School "Nadiya"; 


\section{Kyiv, Ukraine. The impact of communication with animals on the mental state}

of children with neuropsychiatric diseases and visual impairments.

Key words: zootherapy, psycho-correction, children with neuropsychiatric diseases, children with visual impairments, children with disabilities.

Formulation of the problem. The sources of scientific literature lack a clear classification and structure of negative mental states regarding the predominance or presence of their individual species in a given age period, the corresponding psychodiagnostic tools are insufficient, methods of psycho-correction of negative mental states remain insufficiently developed and theoretically justified. Among the recommendations of psychocorrectional interventions there is no method of animal therapy, this issue is not sufficiently developed and poorly covered in scientific sources, while the use of animal assistants for treatment and rehabilitation purposes is becoming increasingly popular and common throughout the world, which is also observed in Ukraine.

Formulating the purpose of the article: to justify zoopsychological mechanisms and evaluate the effectiveness of psychocorrectional effects of animals.

Presenting main material. As a result of monitoring the reactions of children in animals and their attitude towards them, we identified four types of response: I - adequate responses $(\approx 65 \%)$; II - not quite adequate reactions $(\approx$ $23 \%$ ); III - absolutely inadequate reactions $(\approx 7 \%)$; IV - rejection of the animal (no reaction) $(\approx 5 \%)$.

Communication with animals reduces the manifestations of aggression, has a positive effect on communication and the emotional state of the individual. The accumulation of aggressiveness, combined with a decrease in communication links, limited communication, lack of positive emotions, can cause the appearance of negative mental states and lead to the neurotization of the individual.

Communication with animals in the process of psycho-correction reduces the threshold of aggressiveness, which is of great psycho-prophylactic importance. 
Conclusions and perspectives of further research. Psychological correction based on zootherapy, due to the fact that interaction is organized indirectly through animals, helps to solve communicative and personal problems, create a positive motivation for success, reduce the manifestation of negative behaviors and unmotivated aggression, broaden the spectrum of emotions, provide an opportunity to relieve emotional tension waiting and directing activity.

Ключові слова: зоотерапія, психокорекція, діти 3 психоневрологічними захворюваннями, діти з вадами зору, діти з інвалідністю

Постановка проблеми. Світ людей та тварин нерозривно пов'язані між собою. Здавна люди не лише оточували себе живими істотами, а й міфологізували ix появу, наділяли тварин людськими емоціями та приписували їм надзвичайні здібності. Прислухаючись до філософів давнини, звернемося до певних висловів. Давньогрецький філософ Анаксагор називав людину найрозумнішою серед тварин. Сократ характеризував людину як найпрекраснішу тварину. Платон порівнював людину з домашньою твариною і вважав, що одна і та ж сама душа може тимчасово перебувати в тілах різних тварин та людей. Аристотель стверджував, що вивчення всіх організованих істот може бути узагальненим, в душі тварини бачив початкові форми функцій, притаманних людській душі, і порівнював душу дитини 3 душею вищих тварин. Люди ще в давнину розуміли терапевтичну цінність птахів та тварин. Та й саме життя людей завжди було тісно пов'язане з тваринами, зокрема зі свійськими [19].

Зоотерапія, або анімалотерапія (від лат. animal - тварина), є одним із видів психотерапії, що заснований на психокорекційному впливі тварин 3 метою поліпшення соціальних, емоційних або когнітивних функцій пацієнта. Сучасна анімалотерапія знаходится на перетині кількох наукових галузей (зокрема: медична психологія, психофізіологія, зоопсихологія, психотерапія, медицина) i широко застосовується при депресії, тривожності, 
роздратованості, напрузі з підвищенням м’язового тонусу, субклінічних порушеннях під час метеопатичних сезонних розладів та багатьох інших розладах і нозологіях $[2,6,9,13,22,23,25,28]$.

У наш час, коли спосіб життя людей все більше віддаляє їх від безпосереднього спілкування 3 природою $\mathrm{i}$ тваринним світом, які потерпають від деструктивного, нищівного антропогенного впливу, а стресогенні чинники сучасного урбаністичного середовища спричиняють невротизацію особистості та інші порушення психічного здоров'я, взаємодія людей і тварин набуває нового значення в прагненні до внутрішньої гармонії, психологічного здоров'я та розвитку, що й обумовлює актуальність теми дослідження [18].

Аналіз останніх досліджень і публікацій. Грунтовних психологічних досліджень, які 6 переконливо доводили ефективність зоотерапевтичних втручань, у науковій літературі $\epsilon$ обмаль, хоча в останні роки таких публікацій стає все більше, зважаючи на актуальність даного питання.

Клінічний досвід лікарів і медичних психологів підтверджує, що психічні стани людини в значній мірі обумовлюють якість піi життя та опірність захворюванням, їх урахування підвищує результативність лікувально-реабілітаційного процесу та ефективність профілактики захворювань серед населення [14].

Сьогодні людина розуміється як біопсихосоціальна істота, в єдності психічного та соматичного [8], і для пізнання цього суб'єктивного компоненту важливим є розуміння сутності людської психіки та свідомості, їі онто- і філогенетичного розвитку.

Медицина і психологія складають нерозривне ціле [27, 28, 31]. Корекція психіки у процесі лікування хворого та психопрофілактики є важливим аспектом професійної діяльності медичних психологів. Поведінка і діяльність людини в будь-який проміжок часу залежать від того, які саме особливості психічних процесів і психічних властивостей особистості 
виявляються протягом цього періоду, тобто від їі психічного стану $[15,26]$. Психічні стани, впливаючи на протікання психічних процесів, в разі частого повторення та набуття стійкості, можуть стати властивістю особистості [15, 16]. Розрізняють психічні стани, що характеризують афективну та вольову сфери психічної діяльності людини, і стани свідомості та уваги. Психічні стани кожної з цих груп мають спільні характеристики, що відображають їх найбільш типові, стрижневі особливості: «напруження-вирішення» для групи вольових станів, «задоволення-незадоволення» - для групи афективних станів та «сон-активація» для групи станів свідомості та уваги [14-16]. Загалом, класифікація станів ще не завершена і робота в цьому напрямі йде на рівні багатьох світових психологічних наукових шкіл. Тому найбільш інформативною формою вираження суті психічних станів служить опис окремих конкретних станів людини [14-16].

Психічні стани містять у собі, як правило, емоційний та вольовий компоненти. В медичній психології клініко-психологічне значення мають такі психічні стани людини, як втома, настрій, страх, стрес, афект, тривога, гнів, хвилювання, сором, радість тощо [1, 15, 16]. До негативних вольових станів відносять стани апатії, нудьги, нерішучості, невпевненості, байдужості, безнадійності, відсутності мотивації, втоми, пасивності тощо [1, 15, 16]. Найбільшу групу негативних психічних станів складають емоційні стани, серед яких вагоме місце посідають наступні: хвилювання, тривога, страх, паніка, гнів, афект, незадоволення, сум, горе, розпач, пригніченість, емоційна напруга, ненависть, фрустрація, агресія, депресія і т.п. [1, 15, 16]. Емоційні негативні стани мають вікові та індивідуальні особливості [14, 26, 31]. Емоційний компонент, будучи тією чи іншою мірою найбільш характерним для переважної більшості психічних станів, є базовим для розгортання всіх інших, в тому числі і негативних, психічних станів [14, 26, 31].

Симптоматичні прояви психічних станів утоми та перевтоми 
детерміновані характером діяльності, індивідуальними особливостями людини та умовами середовища іiі існування, тому практична оцінка стану втоми повинна проводитися на основі врахування багатогранності змін окремих функцій та дієздатності людини [14-16, 31].

Настрій визначається як відносно тривалий, стійкий психічний стан помірної або слабкої інтенсивності, що виявляється як позитивний або негативний емоційний фон психічного життя індивіда [14-16]. Настрій, впливає на ставлення людини до свого оточення та істотно залежить від иï фізичного стану: нездужання, сильне стомлення, недосипання пригнічує настрій, тоді як міцний сон, здоровий відпочинок, фізична бадьорість сприяють піднесеності настрою [14-16, 31].

Страх - це психічний стан, обумовлений емоційною реакцією на справжню чи уявну небезпеку, що може характеризуватися депресивними проявами, неспокоєм, нервуванням, прагненням вийти з неприємної ситуації. Страх заважає конструктивній діяльності, негативно впливає на когнітивні процеси, зокрема, сприймання, пам’ять, мислення та ін. [1, 14-16, 31].

Тривожний стан пов’язується 3 почуттям страху, пояснюється як гальмівний стан і свідчить про недостатню пристосованість до оточуючого, неспроможність швидко і адекватно реагувати на його зміну $[1,14-16,31]$.

Хвилювання - поширений психічний стан людини, що характеризується синдромом підвищеного збудження, напруження і страху, та пов'язаний 3 негативними передчуттями людини. Стан хвилювання особливо виразно виявляється у дитячому та юнацькому віці [1. 14-16, 31$]$.

Часті стресові ситуації змінюють психічні властивості особистості, яка стає більш сприйнятливою до негативних впливів [14-16, 27, 29, 31]. Істотні порушення психічної діяльності і здоров'я людини спостерігаються у випадках, коли вона не може вплинути на стресову ситуацію, почуває себе приреченою. Однією 3 форм стресу є фрустрація - емоційний стан, що виникає внаслідок непереборної перешкоди на шляху до задоволення 
потреби. Фрустрація веде до змін в поведінці особистості, таких реакцій як агресія або депресія [29].

Спокій - стан психофізіологічної і психічної рівноваги, що настає внаслідок зняття психологічної напруги або тоді, коли обставини, життєва ситуація особистості повністю іiі задовольняють. Людині в стані спокою притаманні рівновага активності та реактивності, перевага свідомості над почуттям, зріла вразливість, емоційна витримка [14-16].

Радість є психічним станом позитивно забарвленої емоційної піднесеності. Почуття радості може обумовлюватися видом діяльності радість пізнання, радість творчості, а також радість спілкування з приємними людьми. В дитячому віці радість може виникати і без достатньої, на перший погляд, причини [14-16].

Агресія - це емоційний стан, що характеризується імпульсивною поведінкою, афективними переживаннями гніву, злості, прагненням заподіяти іншому травму (фізичну чи моральну); це вмотивована деструктивна поведінка, яка суперечить нормам і правилам поведінки людей у суспільстві та завдає шкоди об'єктам нападу. В залежності від способу поведінки у фрустраційній чи конфліктній ситуації, виділяють вербальну, фізичну та опосередковану види агресії [1, 14-16, 24]. Стан агресії, в залежності від його негативних наслідків, часто може трансформуватися в інші, також переважно негативні, психічні стани $[1,24]$.

Стан депресії - це негативний психічний стан, центральною ланкою якого є знижений настрій різноманітних відтінків (пригніченість, нудьга, туга, тривога), що поєднується зі зниженням життєвого тонусу, низькою самооцінкою, уповільненням темпу більшості пізнавальних процесів, руховим збідненням $[1,14-16]$. У дітей приховані депресивні стани, крім соматичних симптомів, також можуть проявлятися через погіршення успішності [14-16, 31].

Апатія - індиферентність, інертність, байдужість, відсутність інтересу до зовнішніх явищ і подій, що може продукувати інші негативні явища в 
емоційній сфері, збіднює спектр емоційних проявів характеризується істотним зниженням настрою (що засвідчує його зв'язок із депресією), емоційного тонусу, проявами песимізму в світосприйнятті тощо [1, 14-16].

Психічний стан пасивності свідчить про слабкість процесів збудження та гальмування, відноситься до групи вольових станів та має негативні наслідки, що деструктивно впливають на практичну діяльність особистості. Стан астенії характеризується ослабленістю психічних потенціалів особистості, підвищеною втомлюваністю, істотними змінами в емоційній сфері. На фоні стану астенії відбуваються зміни і у вольовій та поведінковій сферах, з'являються стани нерішучості, байдужості та пасивності [14-16].

Відомо що свійські тварини вгадують настрій господарів, підлаштовуються під них, а отже, впливають на психоемоційний стан людини $[6,10,25,30]$. Хоча люди спостерігали та використовували це здавна, проте дослідження впливу тварин на психоемоційні стани людини проводилося недостатньо. За визначенням видатного етолога Л. В. Крушинського, мислення або розумова діяльність - це здатність тварини вловлювати емпіричні закони, що пов'язують предмети та явища зовнішнього світу, оперувати цими законами в новій для неї ситуації для побудови адаптивного поведінкового акту [21].

Фахівці розрізняють діяльність за участю тварин і терапію за участю тварин (таблиця 1.) [30].

Діяльність за участю тварин може бути пасивною або активною. Як приклад першої, можна навести спостереження за тваринами в їх природному середовищі існування. При цьому хворі люди не контактують безпосередньо $з$ тваринами, а отримують відчутну користь для здоров’я просто від їх присутності - наприклад, якщо в реабілітаційних палатах для людей похилого віку $є$ клітини 3 птахами, то рівень депресії у них знижується. Спілкування з природою, «розчинення в ній» також відноситься до цієї форми спілкування з тваринами. При активній діяльності за участі тварин, пацієнти грають з ними або за ними доглядають $[6,11,13,19,22]$. 


\section{Види взаємодії людини із тваринами}

(за А.В. Суботіним, Л.Л. Ращевською)

\begin{tabular}{|c|c|}
\hline Види взаємодії & Зміст взаємодії \\
\hline $\begin{array}{l}\text { Пасивна діяльність за } \\
\text { участю тварин }\end{array}$ & $\begin{array}{llr}\text { Tерапевтичний } & \text { ефект досягається шляхом } \\
\text { спостереження } & \text { за тваринами в штучному або } \\
\text { природному середовищі існування(рибки в } & \text { в } \\
\text { акваріумі, різні види тераріумів, тварини у вольєрах, } \\
\text { відвідування природних парків) }\end{array}$ \\
\hline $\begin{array}{l}\text { Активн } \\
\text { участю }\end{array}$ & $\begin{array}{l}\text { Терапевтичний ефект досягається шляхом } \\
\text { здійснення активних дій, у які залучені тварини (гра } \\
\text { з тваринами, догляд за тваринами тощо) }\end{array}$ \\
\hline $\begin{array}{l}\text { Терапія за участю } \\
\text { тварин }\end{array}$ & $\begin{array}{l}\text { Терапевтичний ефект досягається через активну } \\
\text { взаємодію людини із твариною як рівноправних } \\
\begin{array}{l}\text { партнерів (тварина є включеною в процес, } \\
\text { своєрідним «лікарем») }\end{array}\end{array}$ \\
\hline
\end{tabular}

Терапія за участю тварин є цілеспрямованим втручанням, при якому тварина $є$ повноправним учасником лікувального процесу, від неї багато в чому залежить терапевтичний ефект. Для такої терапії потрібні не тільки спеціально підготовлені тварини, а й особливо навчений персонал. В ідеалі в ній беруть участь тренер або дресирувальник, лікар і психолог $[6,9,13]$. Лікувальні фактори зоотерапії обумовлені її впливом на канали сприйняття.

В джерелах наукової літератури відсутня чітка класифікація та структура негативних психічних станів щодо переважання чи наявності їх окремих видів в тому чи іншому віковому періоді, $є$ недостатнім відповідний психодіагностичнй інструментарій, залишаються недостатньо розробленими i теоретично обгрунтованими методики психокорекції негативних психічних станів. Серед рекомендацій психокорекційних втручань немає методики анімалотерапії, дане питання взагалі недостатньо розроблене та мало висвітлене в наукових джерелах, в той час як у всьому світі використання тварин-асистентів 3 лікувально-реабілітаційною метою стає все більш популярним і поширеним, що спостерігається також і в Україні $[2,4,6]$. 
Методологічною основою дослідження є цілісне розуміння людини як біопсихосоціальної істоти, яка має тілесний, душевний і духовний рівні розвитку та еволюційно поєднана з тваринним світом, засноване на працях I. П. Павлова, В. О. Вагнера, О. М. Леонтьєва, К. Е. Фабрі, С. Л. Крушинського, Н. М. Ладигіної-Котс, В. Ф. Войно-Ясенецького (Св. Луки Кримського), Г. Т. Терешкевич (с. Діогени) та інших науковців, теоретичні підходи до розуміння психічних процесів, станів, властивостей особистості, наукові положення щодо співвідношення біологічного та соціального у психіці людини Л. С. Виготського, Г. С. Костюка; генетичний підхід до дослідження емоційно-почуттєвої сфери, який представлений у працях В. К. Вілюнаса, М. Д. Левітова, С. Д. Максименка та ін.; негативних психічних станів - О. І. Захарова, А. М. Прихожан, А. С. Співаковської та ін.; теоретичні аспекти психокорекційної роботи, розроблені П. В. Лушиним, О. Ф. Бондаренко та ін. $[7,12,15,20,26-31]$.

Формулювання мети статті: обгрунтувати зоопсихологічні механізми та визначити ефективність психокорекційного впливу тварин.

Виклад основного матеріалу. Методами дослідження є: теоретикоаналітичний, медико-статистичний, психодіагностичний, клінікопатопсихологічний, систематизацій, теоретичного моделювання. Відповідно використовувалися наступні методики дослідження: психодіагностичні (тест САН (Самопочуття, Активність, Настрій), самооцінка психічних станів Г. Айзенка, колірний тест Люшера, тест руки Вагнера (діагностика агресивності), Клінічний опитувальник для виявлення та оцінки невротичних станів, проективна методика «Фізіономічний тест Куніна»), статистичної обробки та аналізу результатів (t-критерій Стьюдента для пов'язаних i незалежних сукупностей, кореляційний аналіз) [3, 5, 17].

Матеріал дослідження - діти з інвалідизуючими психоневрологічними захворюваннями та вадами зору.

Діти 3 інвалідизуючими психоневрологічними захворюваннями в кількості 62 особи (експериментальна група I) були відібрані рандомізованим 
чином з 420 учнів СЗШ «Надія» м. Києва. Iз дітей 3 вадами зору, які навчаються в спеціальному інернаті № 5 м. Києва, для участі в дослідженні рандомізованим чином було відібрано 37 осіб (експериментальна група II).

Обидві групи були співставні за віком, статтю та інтелектуальним розвитком, відрізнялися симптоматикою основного захворювання. Серед 37 осіб із вадами зору, лише 2 дітей були слабкозорими, вони бачили оточуючі предмети у вигляді неясних тіней. Інші 35 досліджуваних дітей цієї групи були повністю сліпі від народження. В іншому, їх фізичний i розумовий розвиток відповідали віковій нормі. Учні ж спеціальної загальноосвітньої школи «Надія», навпаки, проблем із органами сприймання не мали, однак у деяких із них (6 осіб) сприймання оточуючого світу було порушене через наявність продуктивної симптоматики в структурі основного захворювання (слухові та зорові галюцинаціі), втім, на момент дослідження ці діти знаходилися в стані ремісії та не виявляли даної симптоматики. Також серед досліджуваних дітей - учнів СЗШ «Надія» було 17 осіб із важкими розладами моторики, вони хворі на ДЦП та пересуваються на інвалідних візочках. Серед досліджуваних учнів СЗШ «Надія» були також діти 3 гіперактивністю, симптомами аутизму, судомними нападами, депресивним синдромом, соціалізованими та не соціалізованими розладами поведінки.

Психокорекційна програма за участі тварин-асистентів організовується в тісній співпраці лікарів, психологів та зоотерапевтів. Провідною метою психокорекційної програми за участі тварин $є$ корекція психоемоційної і вольової сфер особистості $[2,6,9,12,13,22,23,28]$. Невід’ ємною складовою кожного заняття $є$ елементи рефлексії та обов'язковий зворотний зв'язок, який необхідно сформувати також і для тварини-терапевта, отримати від неї відгук, зрозуміти їі переживання [10, 12, 19, 30].

Планування роботи по взаємодії «дитина-тварина» враховувало чотири послідовні ланки, що представлено в таблиці 2.

В результаті спостереження за реакціями дітей на тварин і ставленням до них, нами було виокремлено чотири типи реагування (відсоткові 
співвідношення вирахувані на основі реакцій на тварин досліджуваних дітей із інвалідизуючими психоневрологічними захворюваннями,- учнів СЗОШ «Надія»):

I - адекватні реакції $(\approx 65 \%)$;

II - не зовсім адекватні реакції $(\approx 23 \%)$;

III - зовсім неадекватні реакції $(\approx 7 \%)$;

IV- несприйняття тварини (відсутність реакції) $(\approx 5 \%)$.

Таблиця 2.

Планування роботи по взаємодії «дитина-тварина»

\begin{tabular}{|l|l|l|}
\hline \multirow{2}{*}{$\begin{array}{l}\text { № } \\
\text { 3/п }\end{array}$} & \multicolumn{1}{|c|}{ Ланка } & \multicolumn{1}{c|}{ Вплив } \\
\hline 1. & \multirow{2}{*}{ Контакт } & Візуальний \\
\cline { 3 - 3 } & & Аудіальний \\
\cline { 3 - 4 } & & Кінестетичний \\
\hline 2. & Відношення & Сприйняття дитиною тварини \\
\hline 3. & Дії & Реакція дитини на певну тварину \\
\hline 4. & Результат контакту & Психокорекція негативних психічних станів \\
\cline { 3 - 4 } & & Позитивні емоції \\
\hline
\end{tabular}

Адекватна реакція виявлялася в розумінні дитини, що перед нею жива істота, в якої є свої потреби, вподобання, характер та реакції на подразники. Дитина усвідомлює необхідність поваги до тварини, а також різницю між своїми потребами (бажаннями) та потребами конкретної тварини.

Не зовсім адекватне сприйняття дитиною тварини характеризувалося тим, що: дитина вирізняє тварин «технічно» (використовуючи підхід «живанежива природа»); здогадується, що тварина має власні потреби, але ігнорує їх на користь своїх власних потреб і бажань; дитина не усвідомлює, що тварина, як жива істота, може втомитися або отримати травму в процесі гри; дитина сприймає спілкування 3 твариною як можливість отримати задоволення від гри, ставиться до тварини як до нової інтерактивної іграшки (тобто, задовольняє власні потреби). 
При неадекватному сприйнятті, дитина не сприймає тварину як живу істоту, ставиться до неї як до рухливого механізму або до іграшки, при цьому до тварини можуть виявлятися негативні емоції з відповідними реакціями (діями).

При відсутності реакції на тварину, дитина не вирізняє эї 3-поміж інших об'єктів, однаково ставиться до об’єктів живої та неживої природи, при цьому вирізняє тварин на малюнках - однак не звертає уваги на живу тварину поруч, виявляючи суто технічне розуміння.

Факторами впливу на результат контакту «дитина-тварина» 3 боку тварини можна зазначити такі, як: теплокровність/холоднокровність, розмір, темперамент, характер та ін.

3 боку дитини, на результат контакту з твариною можуть впливати: стан фізичного і психічного здоров'я, особистісні особливості (характер, темперамент, акцентуаціі), рівень інтелектуального розвитку тощо.

Відповідно, психокорекційні заходи були ефективними лише для тих дітей, яких можна віднести до I та II типів реагування на тварину. Діти III та IV типів не виявили бажання повторної зустрічі з тваринами.

В групі дітей I типу реагування спостерігалося підвищення емоційного фону, поліпшення настрою, збільшення навчального інтересу, спричиненого зацікавленістю та бажаннями дізнатися більше про тварин (конкретних і в цілому) - про їх спосіб життя, сезонні зміни в поведінці, вплив умов життєвого середовища (природнього та штучного), співіснування 3 іншими тваринами тощо. В групі дітей II типу реагування відмічалося: зниження егоцентризму (переключення локусу уваги з внутрішнього на зовнішній - 3 власних потреб на потреби тварин); зниження рівня гіперактивності, завдяки збільшенню рівня уваги (спостереження за поведінкою тварин); стриманість у поведінці; виникнення поваги до тварин як до живих істот; поява інтересу до життя тварин.

Далі представлені результати психодіагностичного дослідження психічних станів до та після психокорекції за участі тварин-асистентів, де 
експериментальна група I - діти з інвалідизуючими психоневрологічними захворюваннями, експериментальна група II - діти з вадами зору (незрячі).

Проведені дослідження за методикою САН (Самопочуття, Активність, Настрій) показало нормалізацію показників психічних станів респондентів за всіма шкалами опитувальника (таблиця 3.).

На початку дослідження, в дітей із інвалідизуючими психоневрологічними захворюваннями та 3 порушеннями зору спостерігалося певне зниження показників самопочуття, активності та настрою, причому якщо в дітей із психоневрологічними захворюваннями меншими були показники самопочуття та настрою, незрячі діти виявляли порівняно меншу активність, тоді як показники самопочуття та настрою, хоч і були нижчими за середньостатистичну норму, виявилися дещо кращими від таких у дітей з психоневрологічними захворюваннями.

Таблиця 3.

Показники самопочуття, активності та настрою (методика САН) у дітей з інвалідизуючими захворюваннями до та після зоотерапевтичної психокорекції

\begin{tabular}{|c|c|c|c|c|c|c|c|c|c|c|c|}
\hline \multirow{3}{*}{$\begin{array}{l}\text { Експе- } \\
\text { римен- } \\
\text { тальна } \\
\text { група }\end{array}$} & \multirow[t]{3}{*}{$\mathrm{f}$} & \multirow[t]{3}{*}{$\mathrm{P}$} & \multicolumn{9}{|c|}{ Середні показники за шкалами САН } \\
\hline & & & \multicolumn{3}{|c|}{ Самопочуття } & \multicolumn{3}{|c|}{ Активність } & \multicolumn{3}{|c|}{ Настрій } \\
\hline & & & $\begin{array}{l}\text { До } \\
\text { психо- } \\
\text { коре- } \\
\text { кції }\end{array}$ & $\begin{array}{l}\text { Після } \\
\text { психо- } \\
\text { корек- } \\
\text { ції }\end{array}$ & $\begin{array}{l}\text { t-критерій } \\
\text { Стьюдента } \\
\text { для } \\
\text { пов'язаних } \\
\text { сукупностей }\end{array}$ & $\begin{array}{l}\text { До } \\
\text { психо- } \\
\text { корек- } \\
\text { ції }\end{array}$ & $\begin{array}{l}\text { Після } \\
\text { психо- } \\
\text { корек- } \\
\text { ції }\end{array}$ & \begin{tabular}{|l|} 
t-критерій \\
Стьюдента \\
для \\
пов'язаних \\
сукупно- \\
стей
\end{tabular} & $\begin{array}{l}\text { До } \\
\text { психо- } \\
\text { корек- } \\
\text { ції }\end{array}$ & $\begin{array}{l}\text { Після } \\
\text { психо- } \\
\text { корек- } \\
\text { ції }\end{array}$ & \begin{tabular}{|l} 
t-критерій \\
Стьюдента \\
для \\
пов'язаних \\
сукупно- \\
стей
\end{tabular} \\
\hline I & 60 & $<0,05$ & 4,3 & 5,2 & tспост>tкрит & 4,8 & 5,1 & tспост> $>$ крит & 4,2 & 5,5 & $\begin{array}{c}\text { tспост>tкр } \\
\text { ит }\end{array}$ \\
\hline II & 35 & & 4,6 & 5,3 & tспост>tкрит & 4,0 & 5,2 & tспост>tкрит & 4,6 & 6,4 & $п$ \\
\hline
\end{tabular}

Після проведеної зоотерапевтичної корекції за участі тварин, в досліджуваних дітей відбулося покращення самопочуття, активності та настрою, показники за всіма шкалами тесту нормалізувалися до меж середньостатистичної норми, крім показника настрою в незрячих дітей, який підвищився більш істотно, та перевищив середньостатистичний. 
В таблиці 4. представлені результати виявлення негативних психічних станів особистості в досліджуваних за тестом Г. Айзенка та їх динаміка після зоотерапевтичної психокорекції.

Як видно 3 даної таблиці, дітям із психоневрологічними захворюваннями притаманні такі негативні психічні стани, як тривожність, фрустрація, агресивність та ригідність. Після психокорекційного спілкування 3 тваринами, показники за всіма 4 шкалами тесту самооцінки психічних станів статистично значимо (tспост>tкрит) змінилися в бік нормалізації: якщо до психокорекції вони мали високі значення, то після спілкування 3 тваринами знизилися до середніх цифр. В даній досліджуваній групі найбільше методика зоотерапевтичної психокорекції вплинула на негативні психічні стани фрустрації та агресії.

Таблиця 4.

Показники самооцінки психічних станів досліджуваних дітей за

методикою Г. Айзенка до та після зоотерапевтичної психокорекції

\begin{tabular}{|c|c|c|c|c|c|c|c|c|c|}
\hline \multirow{2}{*}{\multicolumn{2}{|c|}{$\begin{array}{l}\text { Показники } \\
\text { психічних станів } \\
\text { (середні значення) }\end{array}$}} & \multicolumn{2}{|c|}{ Тривожність } & \multicolumn{2}{|c|}{ Фрустрація } & \multicolumn{2}{|c|}{ Агресивність } & \multicolumn{2}{|c|}{ Ригідність } \\
\hline & & до & Після & до & після & до & після & до & $\begin{array}{l}\text { Післ } \\
\text { я }\end{array}$ \\
\hline \multirow{2}{*}{$\begin{array}{l}\text { Експеримен- } \\
\text { тальна група }\end{array}$} & I & 16,3 & 10,2 & 17,9 & 9,1 & 19,2 & 9,4 & 18,0 & 11,8 \\
\hline & II & 17,1 & 9,0 & 18,8 & 11,7 & 16,6 & 8,4 & 17,0 & 9,2 \\
\hline \multicolumn{2}{|c|}{$\begin{array}{l}\text { t-критерій } \\
\text { Стьюдента } \\
\text { для пов позаних } \\
\text { сукупностей }\end{array}$} & \multicolumn{8}{|c|}{ tспост> $>$ tкрит } \\
\hline
\end{tabular}

В групі незрячих дітей, більш вираженими були такі негативні психічні стани, як фрустрація та тривожність. Агресивність, яку виявляли ці діти, мала захисний характер. Після спілкування 3 тваринами, показники цих негативних психічних станів істотно змінилися в бік нормалізації.

Що стосується ригідності, то в незрячих дітей, у яких виявлено високі показники за даною шкалою тесту, вона мала захисний характер, тому після психокорекційного спілкування 3 тваринами, коли були подолані негативні психічні стани тривоги та фрустрації, показник ригідності істотно знизився, а 
от у групі дітей із інвалідизуючими психоневрологічними захворюваннями ригідність визначається не лише як негативний психічний стан, а як патопсихологічний симптом, притаманний основному захворюванню, тому в даній досліджуваній групі показник ригідності, хоч і знизився від високих до середніх параметрів, однак не настільки значимо. Таким чином, психокорекція за участі тварин-асистентів може використовуватися не лише як лікувально-реабілітаційний, а й як психопрофілактичний засіб, сприяючи нормалізації психічних станів особистості.

Статистично достовірну різницю в настрої досліджуваних дітей із психоневрологічними захворюваннями та незрячих дітей до та після занять із тваринами було виявлено за допомогою фізіономічного тесту Куніна (таблиця 5.).

Таблиця 5.

Динаміка психоемоційних станів досліджуваних дітей в процесі зоотерапевтичної психокорекції (тест Куніна)

\begin{tabular}{|c|c|c|c|c|c|c|c|c|}
\hline \multirow{4}{*}{ Настрій } & \multicolumn{8}{|c|}{ Експериментальна група } \\
\hline & \multicolumn{4}{|c|}{$\mathrm{I}$} & \multicolumn{4}{|c|}{ II } \\
\hline & \multicolumn{2}{|c|}{$\begin{array}{c}\text { До } \\
\text { психокорекції }\end{array}$} & \multicolumn{2}{|c|}{$\begin{array}{c}\text { Після } \\
\text { психокорекції }\end{array}$} & \multicolumn{2}{|c|}{$\begin{array}{c}\text { До } \\
\text { психокорекції }\end{array}$} & \multicolumn{2}{|c|}{$\begin{array}{c}\text { Після } \\
\text { психокорекції }\end{array}$} \\
\hline & абс.число & $\%$ & абс.число & $\%$ & абс.число & $\%$ & $\begin{array}{l}\text { абс.число } \\
\end{array}$ & $\%$ \\
\hline Дуже поганий & 0 & 0 & 0 & 0 & 0 & 0 & 0 & 0 \\
\hline Поганий & 4 & 6,5 & 0 & 0 & 0 & 0 & 0 & 0 \\
\hline Знижений & 23 & 37,1 & 7 & 11,4 & 12 & 32,4 & 2 & 5,4 \\
\hline $\begin{array}{l}\text { Спокійний, } \\
\text { врівноважений }\end{array}$ & 17 & 27,4 & 19 & 30,6 & 25 & 67,6 & 18 & 48,7 \\
\hline $\begin{array}{l}\text { Гарний, } \\
\text { бадьорий }\end{array}$ & 16 & 25,8 & 27 & 43,5 & 0 & 0 & 13 & 35,1 \\
\hline Дуже гарний & 2 & 3,2 & 9 & 14,5 & 0 & 0 & 4 & 10,8 \\
\hline Всього & 62 & 100 & 62 & 100 & 37 & 100 & 37 & 100 \\
\hline $\begin{array}{c}\text { t-критерій } \\
\text { Стьюдента для } \\
\text { пов’язаних } \\
\text { сукупностей }\end{array}$ & & $\begin{array}{r}\mathrm{f}= \\
\text { tкрит } \\
\text { tспост } \\
\text { tспос }\end{array}$ & $\begin{array}{l}1 \\
2,000 \\
13,761 \\
\text { tкрит }\end{array}$ & & & $\begin{array}{l}\text { t } \\
\text { tкри } \\
\text { tспос } \\
\text { tспос }\end{array}$ & $\begin{array}{l}36 \\
=2,028 \\
=8,357 \\
>\text { tкрит }\end{array}$ & \\
\hline
\end{tabular}

При початковому тестуванні, 23 (37,1\%) із 62 досліджуваних дітей 3 інвалідизуючими психоневрологічними захворюваннями охарактеризували 
свій настрій як знижений, і 4 (6,5\%) дитини - як поганий, в 17 (27,4\%) дітей спостерігався спокійний настрій, в 16 (25,8\%) - гарний (впевненість у собі, задоволення), і лише $2(3,2 \%)$ із 62 досліджуваних дітей оцінили свій настрій як дуже гарний (оптимістичність, відчуття щастя, доброзичливість). Після проведення занять із тваринами, лише у $7(11,4 \%)$ досліджуваних дітей настрій залишався зниженим, 19 (30,6\%) визначили свій настрій як спокійний, гарним назвали свій настрій 27 (43,5\%) дітей, а дуже гарним - 9 (14,5\%). Тобто, було зафіксовано істотний психокорекційний вплив спілкування 3 тваринами в умовах зоопарку на настрій дітей 3 інвалідизуючими психоневрологічними захворюваннями.

У незрячих дітей, перш ніж проводити дослідження за даною проективною методикою, було розроблено та апробовано спеціальний стимульний матеріал, що дозволяє сприймати тестові малюнки тактильно. Було змодельовано два варіанти об’ємних зображень облич, із яких 3 тестовою метою використаний той, результати якого корелювали із такими в осіб із нормальним зором. В процесі розробки стимульного матеріалу було 3'ясовано, що незрячі діти не уявляють реальні мімічні вирази облич, їм важко співвіднести настрій людини з його мімічними проявами. Тому було проведено декілька роз'яснювальних занять, і фактично, досліджувані діти стали співавторами розробленого стимульного матеріалу до даного тесту.

В незрячих дітей, до психокорекції спостерігався переважно спокійний настрій (25 осіб, або 67,6\%), а 12 осіб (32,4\%) охарактеризували свій настрій як знижений. На відміну від дітей із психоневрологічними захворюваннями, незрячі діти не надавали своєму настрою полярних характеристик (поганий або дуже поганий - гарний або дуже гарний).

Покращення настрою в досліджуваних дітей напряму пов’язане із застосуванням психокорекції за участі тварин, результати розрахунків статистично значимі. В усіх досліджуваних групах кореляційний зв’язок між психокорекційним втручанням і покращенням настрою виявився прямим, сила зв’язку висока, залежність ознак статистично значима. За критерієм 
Стьюдента, покращення психічного стану після психокорекції в усіх досліджуваних групах є статистично значимим.

Результати психодіагностики агресивності за тестом руки Вагнера, що проводився в усіх досліджуваних дітей до та після психокорекції із залученням тварин-асистентів, представлені в таблиці 5.

Найнижчий рівень агресії спостерігався в незрячих дітей (яким тест Вагнера пропонували за допомогою об’ємних зображень руки). Втім, у даного контингенту досліджуваних розцінювати результати за тестом Вагнера слід 3 обережністю, тому що вони не бачать рук, а, отже, не користуються жестовою комунікацією на практиці. Водночас, досліджувані розуміли надані інструкції та могли співставити стимульний матеріал руки певної форми з відповідним психічним станом.

Таблиця 5.

Показники агресивності досліджуваних дітей за тестом руки Вагнера в динаміці до та після зоотерапевтичної психокорекції

\begin{tabular}{|c|c|c|c|c|}
\hline \multirow[b]{3}{*}{ Шкала } & \multicolumn{4}{|c|}{ Експериментальна група } \\
\hline & \multicolumn{2}{|c|}{$\mathrm{I}$} & \multicolumn{2}{|c|}{ II } \\
\hline & До & Після & До & Після \\
\hline $\mathrm{A}$ & 3 & 2 & 3 & 1 \\
\hline $\mathrm{y}$ & 4 & 2 & 1 & 1 \\
\hline $\mathrm{C}$ & 4 & 2 & 2 & 1 \\
\hline $\mathrm{E}$ & 1 & 3 & 3 & 4 \\
\hline $\mathrm{K}$ & 1 & 3 & 1 & 3 \\
\hline 3 & 4 & 3 & 2 & 3 \\
\hline Д & 3 & 2 & 0 & 1 \\
\hline IB & 4 & 2 & 1 & 0 \\
\hline АБ & 0 & 1 & 0 & 2 \\
\hline ПБ & 2 & 2 & 3 & 3 \\
\hline $\begin{array}{l}\text { Сумарний бал } \\
\text { агресивності }\end{array}$ & -3 & -7 & -4 & -8 \\
\hline
\end{tabular}

Діти 3 інвалідизуючими психоневрологічними захворюваннями показали більш високий рівень агресії, ніж діти з вадами зору, однак все-таки зі знаком мінус. На зменшення показника агресії в даній групі вплинув високий показник залежності, тим більше що діти 3 вадами моторики, 
розуміючи жестову мову, самі ïi використовувати нездатні, так само їм складно користуватися власною рукою для виконання різноманітних дій, насамперед пов'язаних із мілкою моторикою.

Після психокорекційних занять за участі тварин, сумарний бал агресивності знизився в обох досліджуваних групах, причому в групі дітей 3 інвалідизуючими психоневрологічними захворюваннями він знизився більше ніж в 3 рази, в групі незрячих дітей - в два рази порівняно $з$ таким на початку дослідження. Таким чином, як можна 3’ясувати на основі даного тесту, спілкування 3 тваринами знижує прояви агресії, позитивно впливає на комунікативність та емоційний стан особистості. Накопичення агресивності, в поєднанні зі зниженням комунікативних зв’язків, обмеженням спілкування, нестачею позитивних емоцій, може спричинити виникнення негативних психічних станів та призвести до невротизації особистості. Спілкування ж із тваринами в процесі психокорекції, дозволяє знизити поріг агресивності, що має важливе психопрофілактичне значення.

Висновки. В джерелах наукової літератури відсутня чітка класифікація та структура негативних психічних станів щодо переважання чи наявності їх окремих видів в тому чи іншому віковому періоді, $є$ недостатнім відповідний психодіагностичний інструментарій, залишаються недостатньо розробленими i теоретично обгрунтованими методики психокорекції негативних психічних станів. Серед рекомендацій психокорекційних втручань немає методики анімалотерапії, дане питання взагалі недостатньо розроблене та мало висвітлене в наукових джерелах, в той час як у всьому світі використання тварин-асистентів з лікувально-реабілітаційною метою стає все більш популярним і поширеним, що спостерігається також i в Україні.

В результаті спостереження за реакціями дітей на тварин і ставленням до них, нами було виокремлено чотири типи реагування: I - адекватні реакції; II - не зовсім адекватні реакції; III - зовсім неадекватні реакції; IVнесприйняття тварини (відсутність реакції). 
Спілкування з тваринами знижує прояви агресії, позитивно впливає на комунікативність та емоційний стан особистості, і може бути використане як 3 лікувальною метою, спрямованою на корекцію негативних психічних станів, так і з психопрофілактичною метою.

Психологічна корекція саме на основі зоотерапії, завдяки тому, що взаємодія організовується опосередковано, через тварин, допомагає вирішити комунікативно-особистісні проблеми, створити позитивну мотивацію успіху, знизити прояви негативних форм поведінки та невмотивованої агресії, розширити спектр виявлення емоцій, надає можливість зняти психоемоційне напруження, оптимізувати очікування та спрямувати активність.

Зоотерапія спричиняє ефект позитивного здоров’я, що проявляється через активну взаємодію 3 твариною та прийняття людиною на себе відповідальності за турботу про неї. Це призводить не до припинення негативного психічного стану болю (тілесного чи душевного), а до вироблення пристосувальних механізмів, необхідних для того, щоб бути успішним і долати труднощі.

Автори статті висловлюють подяку колективу Київського міського зоологічного парку загальнодержавного значення, зокрема, Харькову С. В., Кардоновій В. Г., Савон Є. С., Сидоренко І. В., Кіхно І. М., за ініціацію проекту, сприяння організації досліджень та активну участь у іх проведенні.

\section{Список використаних джерел}

1. Алексєєва Л. С. Наслідки страху, тривоги та гніву / Л. С. Алексєєва// Директор школи, 2000. № 6. С. 71-80.

2. Анцупова I. І..Анімалотерапія / I. I. Анцупова //Навколо світу.- N12 (2795).- 2006.

3. Банержі А. Медична статистика зрозумілою мовою: вступний курс / А. Банержі. - М. : Практична медицина, 2007. - 287 с. 
4. Вайолет Оклендер. Вікна в світ дитини. Керівництво 3 дитячої психотерапії / Вайолет Оклендер.- М.: «Клас», 2001.- 336 с.

5. Венгер А. Л. Психологічні малюнкові тести / А. Л. Венгер. - М.: ВЛАДОС, 2003. - 160 c.

6. Верьовкіна О. В. Анімалотерапія як інноваційний та перспективний метод психологічної роботи / О.В. Верьовкіна // Електроний ресурс.- режим доступу: http://apriori-journal.ru/journal-gumanitarnie-nauki/id/1648

7. Виготський Л. С. Вибрані психологічні дослідження / Виготський Л. C.- M.: 1956.- 520 c.

8. Гіляровський В. А. Про взаємодії соматичного та психічного в медицині / В. А. Гиляровський //Лікарська справа.- 1947.- №8.- С. 625-632.

9. Давидова Г. Б. Зоотерапія, як метод у комплексній реабілітації дітей з обмеженими можливостями на базі Єгор'євського реабілітаційного центру «Єгорка»: Комплексна програма реабілітації з екотерапії «Від екології природи до екології душі» / Давидова Г. Б., Маслова Ю. К., Большакова М. A.- М., 2011 [Електронний ресурс].- режим доступу: https://socsp.ru/data/docs/ programma-dlya-detey-s-ogranichennymi-vozmognostyami-rebyatam-o-zveryatah. docx).

10. Данілкіна О. П. Физіологія стресу тварин / О. П. Данілкіна; Краснояр.держ. аграр. ун-т. - Красноярськ, 2016. - 32 с.

11. Дорошина К. М. Психосоціальна діяльність зоопарків / Дорошина К. М., Коваленко В. Х., Фесенюк Н. П. // Академічна студія: щоквартальний науковий часопис CHT «GAUDEAMUS» ПрАТ «ВН3 «МАУП».- 2018.- №3.C. $155-159$.

12. Дубровкін Є. В. Методика проведення виїзних лекцій для дітей інвалідів / С. В. Дубровкін // Науково-просвітницька робота в зоопарках. 2002. - Вип. 1. - С. 144 - 145.

13. Зоотерапія та іiі використання на практиці [Електронний ресурс].режим доступу: https://studbooks.net/1614801/psihologiya/zaklyuchenie 
14. Ігумнова О. Б. Особливості психічних станів та їх діагностики / О. Б. Ігумнова // Проблеми загальної та педагогічної психології: Зб.наук. праць Інституту психології ім. Г. С. Костюка АПН України [гол. ред. Максименко С. Д.] - Т. XI, ч. 4. - К., 2009. - С. 139-149.

15. Ігумнова О. Б. Негативні психічні стани як перешкода самоактуалізації особистості / О. Б. Ігумнова // Освітньо-наукове забезпечення діяльності правоохоронних органів України: матеріали Всеукраїнської наук.-практ. конфер. Серія : Психолого-педагогічні й філологічні науки (Хмельницький, 14 листопада 2008 р.). - Хмельницький : НАДПСУ, 2008. - С. 94- 95.

16. Ігумнова О. Б. Вплив особистісних властивостей на формування негативних психічних станів особистості / О. Б. Ігумнова // Деструктивні емоційні стани учнів: проблеми теорії та практики : зб. матер. міжобласної наук.-практ. конфер. (Вінниця, 18-19 грудня 2009 р.) [заг. ред. С. М. Томчук].-Вінниця: ВОІПОПП, 2010. - С. 30-33.

17. Карелін А. А. Психологічні тести: в 2-х т. [ред. Карелін А. А.]. - М. : ВЛАДОС, 2003. - 248 с.

18. Климова Т. В. Проблема екологічного виховання в умовах екологічної кризи/Т.В. Климова//Успіхи сучасного природознавства.- 2004.- № 3.- С. 66.

19. Коляденко Н. В. Зоопсихологія: Підручник / Н. В. Коляденко.- К.: МАУП, 2019.- $530 \mathrm{c.}$

20. Корсакова Т. А. Розвиток чуттів за допомогою зоотерапії (з досвіду праці в ЦРТДіЮ) / Т. А. Корсакова // Зб. наук. Праць за мат. міжнар. наук.практ. конф. «Наука і освіта в XXI ст.». - Тамбов, 2013. - Ч.18. - С. 78-79.

21. Крушинський Л. В. Вступ в етологію та генетику поведінки / Крушинський Л.В.,Зоріна З.А.,Полєтаєва Л.И., Романова Л.Л.-М.,1983.-174 с.

22. Лавринова М. Зоотерапія та ії застосування в практиці психолога / М. Лавринова // [Електронний ресурс].- режим доступу: http://www.allbest.ru/ 
23. Литвиненко О. Л. Використання методів зоотерапії при роботі 3 дітьми-інвалідами / О. Л. Литвиненко // Методична розробка. - Самара, МОУ ДОД ЦДТ «Ирбис», 2010. - 9 с.

24. Лоренц К. Агресія (так зване зло) [пер. з англ.] / Лоренц К.- М.: Прогрес Універс, 1994.- 272 с.

25. Макарова Н. М. Технології гардено- та зоотерапії в процесі соціальної реабілитації дітей з порушеннями опорно-рухового апарату / Н. М. Макарова // Корекційна педагогіка. - 2013. - № 2. - С. 62-69.

26. Максименко С. Емоційний розвиток дитини / С. Максименко, К. Максименко, О. Главник.- К.: Мікрос-СВС, 2003. - 112 с.

27. Поняття норми і патології, психічного здоров'я та психічної хвороби / Електронний ресурс.- режим доступу: https://studfiles.net/preview/5643737/ page: $10 /$.

28. Подолати хворобу: Психотерапія - зоотерапія - лікування за допомогою тварин [Електронний ресурс].- режим доступу: http://www.mindlabyrinth.ru/additional/illwin/detail.php?sid=75\&pid=961

29. Сельє Г. Стрес без дістресу [пер. с англ.] / Сельє Г. - М.: Прогрес, 1982.- 124 c.

30. Субботін А. В. Лікувальна кінологія. Теоретичні підходи та практична реалізація/А.В. Субботін, Л.Л. Ращевська.-М.:Вид-во «Макцентр», 2004.-71 с.

31. Томчук С. М. Генеза негативних психічних станів молодших школярів та їх корекція / Томчук С. М. // Актуальні проблеми психології: Зб. наук. праць ін-ту психології ім. Г.С. Костюка АПН України. Серія: Екологічна психологія. - К.: Мілєніум, 2005, Т.7. Вип. 6. - С. 372-380.

\section{References}

1. Alexeeva, L. S., (2000), "Consequences of fear, anxiety and anger", Director of school,vol. 6, pp. 71-80.

2. Antsupova, I. I. (2006), “Animalotherapy”, Navkolo svitu, vol. 12(2795). 
3. Banerzhi, A. (2007), Medichna statystykazrozumiloiu movoiu: vstupnyi kurs [Medical statistics in clear language: introductory course], Practical Medicine, Moscow, Ru.

4. Violet Aucklander, (2001), Vikna v svit dytyny. Kerivnytstvo z dytiachoi psykhoterapii, [Windows in the world of a child. Manual on Pediatric Psychotherapy], Clas, Moscow, Ru.

5. Wenger, A. L. (2003), Psykholohichni maliunkovi testy, [Psychological Drawings], VLADOS,Moscow, Ru.

6. Ver'ovkina, O. V. Animaloterapiia iak innovatsijnyi ta perspektyvnyi metod psykholohichnoi roboty, [Animalotherapy as an innovative and perspective method of psychological work], [Online], available at: http://apriori-journal.ru/journalgumanitarnie-nauki/id/1648

7. Vygotsky, L. S. (1956), Vybrani psykholohichni doslidzennia, [Selected psychological research], Moscow, Ru.

8. Gilyarovsky, V.A. (1947), "About the interaction of somatic and mental in medicine", Likars'ka sprava, vol. 8, pp. 625-632.

9. Davydova, G. B. Maslova, Yu. K. and Bolshakova, M. A. (2011), "Zoo as a method of complex rehabilitation of children with disabilities on the basis of Egorjevsk rehabilitation center "Yegorka": Integrated program of rehabilitation from ecotherapy "From the ecology of nature to the ecology of the soul", [Online], available at: https://socsp.ru/data/docs/ program-dlya-detey-s-ogranichennymivozmognostyami-rebyatam- o-zveryatah docx).

10. Danilkina, O. P. (2016), Fyziolohiia stresu tvaryn [Physiology of Animal Stress], Krasnoyarsk. agrar un, Krasnoyarsk, Ru.

11. Doroshina, K. M. Kovalenko, V. H. Fesennyuk, N. P. (2018), "Psychosocial activity of zoos", Academichna stidia: schokvartal'nyi naukovyi chasopys SNT "GAUDEAMUS", PrAT “VNZ “MAUP”, vol. 3, pp. 155-159.

12. Dubrovkin, Y.V. (2002), "Methodology of conducting on-site lectures for children-invalids", Naukovo-prosvitnyts'ka robota $v$ zooparkakh, vol. 1, pp. 144 145. 
13. Zoology and its use in practice [Online], available at: https://studbooks.net/1614801/psihologiya/zaklyuchenie

14. Igumnova, O. B. (2009)," Peculiarities of mental states and their diagnostics", Problemy zahal'noi ta pedahohichnoi psykholohii: Zb.nauc. prats' Institutu psykholohii im.H.S. Kostiuka APN Ukrainy [hol. red. Maksymenko S. D.],vol. XI, part 4, pp.. 139-149.

15. Igumnova, O. B. (2008), Negative mental states as an obstacle to the selfactualization of personality", Osvitn'o-naukove zabezpechennia diial'nost pravookhoronnykh orhaniv Ukrainy: materialy Vseukrains'koi nauk.-prakt. konfer. Seriia : Psykholoho-pedahohichni j filolohichni nauky (Khmel'nyts'kyj, 14 lystopada 2008 r.), NADPSU, Khmelnitsky, pp. 94-95.

16. Igumnova, O. B. (2010), "Influence of personality traits on the formation of negative psychic states of personality", Destruktyvni emotsijni stany uchniv: problemy teorii ta praktyky : zb. mater. mizhoblasnoi nauk.-prakt. konfer. (Vinnytsia, 18-19 hrudnia 2009 r.) [zah. red. S. M. Tomchuk], VOIPOPP, Vinnitsa, pp. 30-33.

17. Karelin, A. A. (2003), Psykholohichni testy: $v 2-k h t$. [Psychological tests: in 2 t.], VLADOS, Moscow, Ru.

18. Klimova, T. V. (2004), "The problem of environmental education in the context of the ecological crisis", Uspikhy suchasnoho pryrodoznavstva, vol. 3, pp. 66.

19. Koliadenko, N. V. (2018), Zoopsykholohiia ta porivnyalna psykholohiia: Pidruchnyk [Zoopsychology: Textbook], MAUP, Kyiv, Ua.

20. Korsakova, T. A. (2013), "Development of senses with the help of zootherapy (from the experience of work in the CSTDiU)", Zb. nauk. Prats' za mat. mizhnar. nauk.-prakt. konf. "Nauka i osvita v KhKhI st, Tambov, 2013 ”, vol. 18, pp. 78-79.

21. Krushinskiy, L. V. Zorina, Z. A. Poletayeva, L. I. and Romanova, L. L., Vstup v etolohiiu ta henetyku povedinky [Introduction to Ethology and Genetics of Behavior ]. Moscow, Ru. 
22. Lavrinova, M. (2010), "Zoo and its application in the practice of a psychologist" [Online], available at: http://www.allbest.ru/

23. Litvinenko. O. L. (2010), Vykorystannia metodiv zooterapii pry roboti z dit'my-invalidamy: Metodychna rozrobka, [Using zooperative methods when working with children with disabilities: Methodical development], MOU DOD CDT "Irbis”, Samara, Ru.

24. Lorenz, K. (1994), Ahresiia (tak zvane zlo), [Aggression (so-called evil)] [trans. from Eng.], Progress University, Moscow, Ru.

25. Makarova, N. M. (2013), "Technologies of gardenode and zoo in the process of social rehabilitation of children with musculoskeletal disorders", Korektsijna pedahohika, vol.2, pp. 62-69.

26. Maksimenko, S. Maksimenko, K. and Glavnik, O. (2003), Emotsijnyj rozvytok dytyny, [Emotional development of a child], Mikros-SVS, Kyiv, Ua.

27. "Concept of norm and pathology, mental health and mental illness", [Online], available at: https://studfiles.net/preview/5643737/ page: $10 /$.

28. "To overcome illness: Psychotherapy - Zoo - Treatment with animals", [Online], available at: http://www.mindlabyrinth.ru/additional/illwin/ detail.php?sid=75\&pid $=961$

29. Selye, G. (1982), Stres bez distresu, [Stress without distress] [trans. from Eng.], Progress, Moscow, Ru.

30. Subbotin, A. V. Raschevskaya, L. L (2004), Likuval'na kinolohiia. Teoretychni pidkhody ta praktychna realizatsiia, [Curative cynology. Theoretical approaches and practical realization], View of McCenter, Moscow, Ru.

31. Tomchuk, S. M. (2005), "Genesis of Negative Mental Conditions of Junior Students and Their Correction", Aktual'ni problemy psykholohii: Zb. nauk. prats' in-tu psykholohii im. H.S. Kostiuka APN Ukrainy. Seriia: Ekolohichna psykholohiia, vol. 7(6), pp. 372-380, Milenium, Kyiv, Ua. 
